Research Article

\title{
Antiobesity activity of Moringa oleifera leaves against high fat diet-induced obesity in rats
}

\author{
Shamsun Nahar ${ }^{1}$, Ferdous Mahmud Faisal ${ }^{2}$, Jalaluddin Iqbal ${ }^{3}$, \\ Md. Mizanur Rahman ${ }^{4}$, Md. Abdullah Yusuf ${ }^{5}$
}

\begin{abstract}
${ }^{1}$ Department of Pharmacology and Therapeutics, Monno Medical College, Manikgonj, Bangladesh

${ }^{2}$ Department of Urology, National Institute of Kidney Diseases and Urology Hospital, Dhaka, Bangladesh ${ }^{3}$ Department of Pharmacology and Therapeutics, Sir Salimullah Medical College, Dhaka, Bangladesh

${ }^{4}$ Principal, Monno Medical College, Manikgonj, Bangladesh ${ }^{5}$ Department of Microbiology, National Institute of Neurosciences and Hospital, Dhaka, Bangladesh
\end{abstract}

Received: 26 May 2016 Accepted: 01 July 2016

*Correspondence to: Dr. Shamsun Nahar, Email: shamsunpharma1stdec @yahoo.com

Copyright: (C) the author(s), publisher and licensee Medip Academy. This is an openaccess article distributed under the terms of the Creative Commons Attribution NonCommercial License, which permits unrestricted noncommercial use, distribution, and reproduction in any medium, provided the original work is properly cited.

\begin{abstract}
Background: Obesity is a condition in which excess body fat is accumulated to an extent that health may be negatively affected. The current study was constructed to evaluate the efficacy of Moringa oleifera leaf powder in management of obesity induced by high cholesterol diet in rats.

Methods: It was an animal (experimental) study and was carried out in the department of pharmacology and therapeutics at Sir Salimullah Medical College, Dhaka in collaboration with Bangladesh Council of Scientific and Industrial Research (BCSIR), Dhaka from January 2009 to December 2009 for a period of one year. 24 Adult male long Evans rats were taken as experimental animal and were grouped as group A and group B. Group A consists of 6 rats (lean control) treated with normal diet without any drugs for 49 days. Group B were treated with high fat diet for 14 days then divided into three groups B1, B2 and B3. Group B1 (obese control) received high fat diet without any drugs for 49 days. Group B2 rats were treated with Moringa Oleifera leaf powder in single dosage of $50 \mathrm{mg} / \mathrm{day} /$ rat orally for 35 days with high fat diet. Group B3 rats were treated with Moringa Oleifera leaf powder in b.d dosage of 50 $\mathrm{mg} /$ day/rat orally for 35 days with high fat diet. These animals were assigned as Moringa Oleifera treatment group.

Results: The results revealed chronic administration of high fat diet in rats led to an increase in body weight that is in group B1 significant increase in thoracic (TC) and abdominal (AC) circumferences as well as body mass index (BMI) in obese group. On the other side, in group B2 treatment with Moringa oleifera leaf powder in single dose reduce food intake and BMI in obese groups. Group B3 treatment with Moringa oleifera leaf powder in b.d. dose resulted in significant decrease in BMI compared to obese control group.

Conclusions: The data of the current study provides experimental evidence for the anti-obesity effect of Moringa oleifera ethanol extract. Thus, present findings reinforce the advice recommending consumption of Moringa oleifera to modulate obesity.
\end{abstract}

Keywords: Moringa oleifera, Obesity, Rats, HFD

\section{INTRODUCTION}

Nowadays Obesity has emerged as a major health problem and risk factor for various disorders worldwide. ${ }^{1}$
According to the World Health Organization (WHO) criteria, obesity is defined by a body mass index (BMI) of $30 \mathrm{~kg} / \mathrm{m}^{2}$ or greater. A BMI above the healthy range of $18-25 \mathrm{~kg} / \mathrm{m}^{2}$ is common in Western cultures and has been linked to both consumption of a Western diet (i.e. high 
saturated fat, high calorie content), and sedentary lifestyles. $^{2}$ Individual is considered obese when the amount of fat tissue is increased to such an extent that physical and mental health are affected and life expectancy reduced. ${ }^{3}$

Overweight and obesity are also defined as abnormal or excessive fat accumulation triggered by disproportion in energy intake and expenditure. ${ }^{4-6}$ In addition to this attenuation in adipogenesis and over expression of pancreatic lipase enzyme which plays a pivotal role in progression of obesity. ${ }^{7}$ The literature review revealed that alteration in dietary habit and less physical exercises, too, increase the frequency of obesity and related disorders. $^{8-9}$ Further, obesity has been found to be associated with various disorders such as osteoarthritis. ${ }^{10}$ ischemic heart diseases (IHD) atherosclerosis, diabetes, and hypertension. ${ }^{11-13}$ A streak of evidence indicates that serotonin, histamine, dopamine, and their associated receptor activities are closely associated with obesity regulation. ${ }^{7}$ Most importantly, strong evidences are available that elicited the role of leptin, ghrelin, and neuropeptides in obesity. ${ }^{14-16}$

Currently, no pharmacological treatment provides sustained weight loss with minimal adverse effects. ${ }^{17,18}$ Thus, attempts have been made to reduce body weight with such pharmacological intervention that possesses minimal side effects. A variety of natural products, including crude extracts and isolated compounds from plants, can induce body weight reduction and prevent diet -induced obesity. ${ }^{19-20}$ Literature review has revealed that various herbal plants such as fucus vesiculosus, citrus aurantium, yacon syrup, curcumin, nigella sativa, camellia synensis, green tea, and black chinese tea are used in the management of obesity. ${ }^{21-24} \mathrm{M}$. O. (M. oleifera) lam that belongs to moringaceae family is commonly known as drumstick tree that possesses various nutritional and medicinal values attributed to its roots, bark, leaves, flowers, fruits, and seeds. ${ }^{25,27}$ Data revealed that most of the parts of the plant possess antimicrobial activity, antidiabetic, hepatoprotective and for cardiac stimulation. ${ }^{28-34}$ Recently, hypocholesterolemic activity of M. oleifera was explored, but its antiobesity activity has not been investigated; hence, the study delineated with antiobesity property of M. oleifera leaves powder in experimentally induced obesity. ${ }^{35}$ The current study was constructed to evaluate the therapeutic potential and the possible mode of action of Moringa oleifera leaf in the treatment of obesity in adult male albino rats. This goal could be achieved through using anthropometric measurements and testing the hypothesis that the anthropometric index may predict obesity adverse effects on lipid profile and the effectiveness of the herbal therapy in the treatment of obesity in rats.

\section{METHODS}

The study was carried out in the department of pharmacology and therapeutics of Sir Salimullah Medical
College in collaboration with Bangladesh Council Of Scientific and Industrial Research (BCSIR) Dhaka during the period of January 2009 to December 2009. 24 adult male long Evans rat, (150-180gm) were taken for this experiment and divided into 4 groups .They were kept in cages in room maintained at 26-290c with a 12 hours light-dark cycle and were allowed free access to food and water ad libitum. 24 Adult male long Evans rats were grouped as group A and group B. Group A consists of 6 rats (lean control) treated with normal diet without any drugs for 49 days. Group B were treated with high fat diet for 14 days then divided into three groups B1, B2 and B3. Group B1 (obese control) received high fat diet without any drugs for 49 days. Group B2 rats were treated with Moringa Oleifera leaf powder in single dosage of 50 $\mathrm{mg} / \mathrm{day} /$ rat orally for 35 days with high fat diet. Group B3 rats were treated with Moringa Oleifera leaf powder in b.d. dosage of $50 \mathrm{mg} / \mathrm{day} / \mathrm{rat}$ orally for 35 days with high fat diet. These animals were assigned as Moringa Oleifera treatment group.

\section{Collection and preparation of plant}

Moringa oleifera leaves were obtained in large quantities from BCSIR campus, Dhaka. Then the leaves were shade-dried by spreading over a sheet of paper under a ceiling fan for five days. The dried leaves were ground in an electric mixer into fine powder and stored in clean sterile glass container. $50 \mathrm{mg}$ of $\mathrm{M}$. oleifera leaf powder/rat/day was administered with normal diet and high fat diet according to experimental design.

\section{Diet formula}

HFD that consists of $58 \%$ fat, $25 \%$ protein and $17 \%$ carbohydrate, lard $(13 \%)$, cholesterol $(1 \%)$, vitamin, and minerals $(0.6 \%)$ as a percentage of total kcal ad libitum, respectively, was administered every HFD that consists of $58 \%$ fat, $25 \%$ protein and $17 \%$ carbohydrate, lard $(13 \%)$, cholesterol $(1 \%)$, vitamin, and minerals $(0.6 \%)$ as a percentage of total kcal ad libitum, respectively, was administered every day 36 . The composition of normal diet consists of $58 \%$ fat, $25 \%$ protein and $17 \%$ carbohydrate, lard $(13 \%)$, cholesterol $(0 \%)$, vitamin, and minerals $(0.6 \%)$. Cholesterol was purchased from Sigma Chemical Co., USA.

\section{Body weight and food intake}

The body weight (gm) was recorded on day one and then weekly consecutively for 49 days using a digital weighing balance. In addition to this, the daily food intake for each group was measured weekly for 49 days.

\section{Anthropometrical measurements}

At the end of the experimental period, rats were fasted overnight (12-14 hours) and the abdominal circumference (AC) (immediately anterior to the forefoot), thoracic circumference (TC) (immediately behind the foreleg), 
body length (nose-to-anus or nose-anus length) were measured in anaesthized rats. The body weight and body length were used to determine the body mass index. ${ }^{37}$

$$
\mathrm{BMI}=\frac{\text { Body weight }(\mathrm{g})}{\text { Length } 2(\mathrm{~cm} 2)}
$$

\section{Statistical analysis}

In the present study, all results were expressed as mean \pm S.E. of the mean. Statistical package for the Social Sciences (SPSS) program, version 14.0 was used to compare significance between each two groups. Difference was considered significant when $\mathrm{P}<0.05$. Percentage difference representing the percent of variation with respect to corresponding control group was also calculated

$$
\% \text { Difference }=\frac{\text { Treated value }- \text { Control value X } 100}{\text { control value }}
$$

\section{RESULTS}

The results of the current study revealed that there is significant increase in the thoracic circumference (TC), abdominal circumferences $(\mathrm{AC})(\mathrm{P}<0.05)$ in obese group with respect to the lean control group. On the other hand, there is significant decrease in TC, AC $(\mathrm{P}<0.05)$ of obese groups treated with Moringa oleifera leaf powder versus the obese control group (Table 1).

Table1: Effect of treatment with Moringa oleifera leaf powder on the anthropometric measurements of obese male rats. Data were represented as mean \pm S.E of 6 rats/group.

\begin{tabular}{|lllll|}
\hline Group & TC $(\mathrm{cm})$ & AC $(\mathbf{c m})$ & Body length (cm) & Body weight (gram) \\
\hline Lean control group A (6) & $11.50 \pm 0.27$ & $14.25 \pm 0.16$ & $23.5 \pm .67$ & $152.50 \pm 1.70$ \\
\hline Obese control group B ${ }_{1}(6)$ & $\begin{array}{l}15.00 \pm 0.27 \\
\mathrm{~A}(30.43 \%)\end{array}$ & $\begin{array}{l}18.25 \pm 0.25 \\
\mathrm{~A}(28.07 \%)\end{array}$ & $23.5 \pm .64$ & $180.83 \pm 3.02$ \\
\hline Obese+m.o single dose group B2 (6) & $\begin{array}{l}12.62 \pm 0.26 \\
\mathrm{~B}_{1}(-15.87 \%)\end{array}$ & $\begin{array}{l}14.87 \pm 0.23 \\
\mathrm{~B}_{1}(-18.52 \%)\end{array}$ & $23.5 \pm .65$ & $169.16 \pm 2.02$ \\
\hline Obese+m.o b.d. dose group B3 (6) & $\begin{array}{l}12.12 \pm 0.23 \\
\mathrm{~B}_{1}(-19.20 \%)\end{array}$ & $\begin{array}{l}14.62 \pm 0.26 \mathrm{~b} \\
\mathrm{~B}_{1}(-19.89 \%)\end{array}$ & $23.5 \pm .63$ & $169.66 \pm 1.04$ \\
\hline
\end{tabular}

The results of the current study revealed that there is significant increase in BMI $(\mathrm{P}<0.05)$ in obese group with respect to the lean control group. On the other hand, there is significant decrease in BMI $(\mathrm{P}<0.05)$ of obese groups treated with Moringa oleifera leaf powder versus the obese control group (Table 2).

Table 2: Effect of treatment with Moringa oleifera leaf powder on BMI of obese male rats.

\begin{tabular}{|lll|}
\hline Group & BMI & \\
\hline Lean control group A (6) & $0.275 \pm .01$ & $\begin{array}{l}\text { A } \alpha \mathrm{B}_{1} \\
21.09 \%\end{array}$ \\
\cline { 1 - 2 } Obese control group $\mathrm{B}_{1}(6)$ & $0.333 \pm .01$ & $\mathrm{~B}_{1} \alpha \mathrm{B}_{2}$ \\
\cline { 1 - 1 } $\begin{array}{l}\text { Obese+m.o single dose group } \\
\text { B2 (6) }\end{array}$ & $0.31 \pm .01$ & $6.90 \%$ \\
\hline $\begin{array}{l}\text { Obese+m.o b.d. dose group } \\
\text { B3 (6) }\end{array}$ & $0.305 \pm .01$ & $\begin{array}{l}\mathrm{B}_{1} \alpha \mathrm{B}_{3} \\
8.40 \%\end{array}$ \\
\hline
\end{tabular}

\section{DISCUSSION}

A growing body of evidence indicates that natural products having anti-obesity effects can be arranged into five categories based on their distinct mechanisms; they produce

- Decreased lipid absorption

- Decreased energy intake
- Increased energy expenditure

- Decreased pre-adipocyte differentiation and proliferation, or

- Decreased lipogenesis and increased lipolysis. ${ }^{38}$

The present study aimed at exploring the potential role of Moringa oleifera in ameliorating the anthropometric measurements, in obese rats. In view of our data, both TC and AC showed significant increase in obese group. As well, BMI revealed significant increase in obese group relative to the lean control group. These findings come in line with the previously reported data that there is fat accumulation in the thoracic and abdominal regions due to the high cholesterol diet. ${ }^{37}$ This indicates that the observed increase in body weight may be due to excessive energy intake and the adipose tissue accumulation. BMI has been stated to be a simple reliable estimate of body fat and obesity in rats. ${ }^{37}$ There are positive correlations between daily lipid intake and BMI as well as fat deposition. $^{39}$

The observed reduction in these anthropometric measures in obese rats as a result of treatment with Moringa oleifera may be due to the inhibition of dietary lipid utilization. Earlier report by Dongmeza and co-workers indicated that a higher inclusion level of moringa extract or its fractions such as saponins and tannins have been associated with the reduced energy required for protein 
and lipid biosynthesis leading to lower growth performance and nutrient utilization. Therefore, moringa has the ability to reduce body lipid and consequently energy retention. ${ }^{40}$

Moringa oleifera extract has beneficial effect on lipid profile through cholesterol reducing effect. Hassarajani et al have investigated its mechanism of action. ${ }^{41}$ Cholesterol homeostasis is maintained by the two processes, cholesterol biosynthesis in which HMG-Co-A reductase catalyzes rate limiting process and cholesterol absorption of both dietary cholesterol and cholesterol cleared from the liver through biliary secretion. The HMG-Co-A/mevalonate ratio has an inverse relationship to the activity HMG-Co-A reductase. The result of Jain et al indicated that the activity of this enzyme is significantly depressed by the ethanolic extract of Moringa oleifera. ${ }^{42}$ Thus, the cholesterol reducing action of the ethanol extract of Moringa oleifera indicated its hypolipidemic activity.

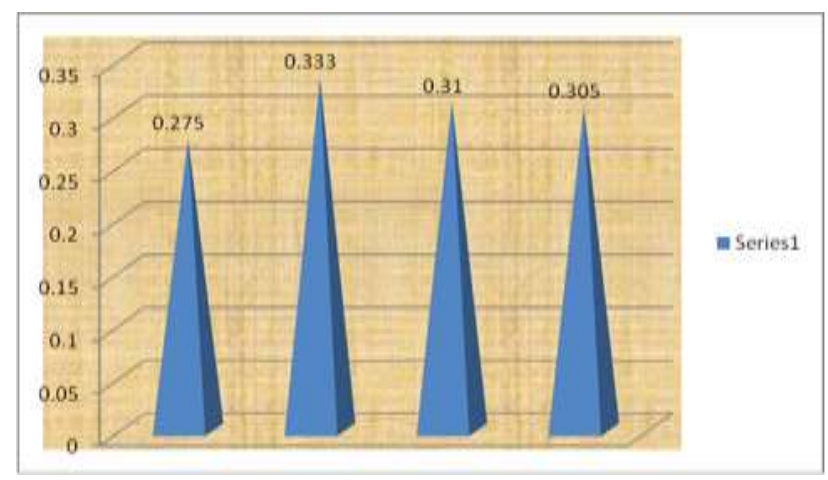

\section{Figure 1: BMI of rats fed a high fat diet and treated with Moringa oleifera leaf powder.}

Moringa oleifera leaf is a good source of phytochemicals including flavonoids, phenolics, carotenoids and $\beta$ sitosterol. ${ }^{43}$ Saluja et al could isolate $\beta$-sitosterol from the stem of a hybrid variety of Moringa oleifera. ${ }^{44} \beta$ sitosterol is a plant sterol with a structure similar to that of cholesterol, except for the substitution of an ethyl group at C24 of its side chain. It is believed that this compound has the ability to lower cholesterol by lowering plasma concentrations of LDL-C. ${ }^{45}$ Therefore $\beta$-sitosterol in the leaves of Moringa oleifera is a bioactive phytoconstituents that accounts for the hypolipidemic influence of Moringa oleifera extract. Moreover, Moringa leaves act as a good source of natural antioxidant due to the presence of various types of antioxidant compounds such as ascorbic acid, flavonoids, phenolics and carotenoids. ${ }^{43}$ Therefore, Moringa oleifera could prevent the oxidization of LDL-C with consequent increase in HDL-C level. $^{46}$

\section{CONCLUSION}

In conclusion, the present study provided experimental evidences for the anti-obesity activity of Moringa oleifera. This effect was documented by the improvement of anthropometric measures Thus, from the present study it can be concluded that $M$. oleifera leaf powder is beneficial to the weight management, which supports its traditional claim. Further, studies are carried out in order to determine the active principle of this plant, followed by the identification of the mechanistic approach of $\mathrm{M}$. oleifera leaf powder that helps in weight management.

Funding: No funding sources

Conflict of interest: None declared

Ethical approval: The study was approved by the Institutional Ethics Committee

\section{REFERENCES}

1. Roh C, Jung U. Screening of crude plant extracts with anti-obesity activity. International Journal of Molecular Sciences. 2012;13(2):1710-9.

2. WHO, Obesity and overweight, WHO: World Health Organization, 2013. Available at http://www.who.int/mediacentre/factsheets/fs311/en/.

3. Graves BW. The obesity epidemic: scope of the problem and management strategies. J Midwifery Womens Health. 2010;55(6):568-78.

4. Spiegelman BM, Flier JS. Obesity and the regulation of energy balance. Cell. 2001;104(4):531-43.

5. Kopelman PG. Obesity as a medical problem. Nature. 2000;404(6778):635-43.

6. Panico S, Iannuzzi A. Dietary fat composition and the metabolic syndrome. European Journal of Lipid Science and Technology. 2004;106(1):61-7.

7. Chandrasekaran CV, Vijayalakshmi MA, Prakash K, Bansal VS, Meenakshi J, Amit A. Review article: herbal approach for obesity management. American Journal of Plant Sciences. 2012;3(7):1003-14.

8. Latha BP, Reddy RM, Ismail SM, Vijaya T. Medicinal plants and their derivatives as potential source in treatment of obesity. Asian Journal of Experimental Biological Sciences. 2010;1(4):719-27.

9. Mangal A, Sharma MC. Evaluation of certain medicinal plants for antiobesity properties. Indian Journal of Traditional Knowledge. 2009;8(4):602-5.

10. Azimi A, Charlot MG, Torp-Pedersen C. Moderate overweight is beneficial and severe obesity detrimental for patients with documented atherosclerotic heart disease. Heart. 2013; 99(9):65560.

11. Nath D, Heemels MT, Anson L. Obesity and diabetes. Natur. 2006;444(7121):839.

12. Dorresteijn JAN, Visseren FLJ, Spiering W. Mechanisms linking obesity to hypertension. Obesity Reviews. 2012;13(1):17-26.

13. Ouimet M. Autophagy in obesity and atherosclerosis: interrelationships between cholesterol homeostasis, lipoprotein metabolism and autophagy in macrophages and other systems. Biochimica et Biophysica Acta. Molecular and Cell Biology of Lipids. 2013;1831(6):1124-33. 
14. Berbari NF, Pasek RC, Malarkey EB. Leptin resistance is a secondary consequence of the obesity in ciliopathy mutant mice. Proceedings of the National Academy of Sciences of the United States of America. 2013;110(19):7796-801.

15. Khazaei M, Tahergorabi Z. Systemic ghrelin administration alters serum biomarkers of angiogenesis in diet-induced obese mice. International Journal of Peptides. 2013;2013:249565:5.

16. Singer K, Morris DL, Oatmen KE. Neuropeptide Y is produced by adipose tissue macrophages and regulates obesity-induced inflammation. PLoS ONE. 2013;8(3):e57929.

17. Gombis B. Pharmacological treatment of obesity. Revista de Medicina-Universidad de Navarra. 2004;48(2):63-5.

18. Pagotto U, Vanuzzo D, Vicennati V, Pasquali R. Pharmacological therapy of obesity. Giornale Italiano di Cardiologia. 2008;9(4):83-93.

19. Han LK, Kimura Y, Okuda H. Anti-obesity effects of natural products. Stud Nat Prod Chem. 2005;30(5):79-110.

20. Rayalam S, Della-Fera MA, Baile CA. Phytochemicals and regulation of the adipocyte life cycle. J Nutr Biochem. 2008;19:717-26.

21. Moro CO, Basile G. Obesity and medicinal plants. Fitoterapia. 2007;71(supple1):S73-S82.

22. Genta S, Cabrera W, Habib N. Yacon syrup: beneficial effects on obesity and insulin resistance in humans. Clinical Nutrition. 2009;28(2):182-7.

23. Ahn J, Lee H, Kim S, Ha T. Curcumin-induced suppression of adipogenic differentiation is accompanied by activation of Wnt/ $\beta$-catenin signaling. American J Physiology. Cell Physiology. 2010;298(6):C1510-C1516.

24. Hasani-Ranjbar S, Jouyandeh Z, Abdollahi M. A systematic review of anti-obesity medicinal plantsan update. $\mathbf{J}$ Diabetes Metabolic Disorders. 2013;12(1):28.

25. Ramachandran C, Peter KV, Gopalakrishnan PK. Drumstick (Moringa oleifera): a multipurpose Indian vegetable. Economic Botany. 1980;34(3):276-83.

26. Anwar F, Latif S, Ashraf M, Gilani AH. Moringa oleifera: a food plant with multiple medicinal uses. Phytotherapy Res. 2007;21(1):17-25.

27. Kumar SP, Mishra D, Ghosh G, Panda CS. Medicinal uses and pharmacological properties of Moringa oleifera. International J Phytomedicine. 2010;2(3):210-6.

28. Bhavasar GC, Guru LV, Chadha AK. Antibacterial activity of some indigenous medicinal plants. Medical-Surgical Nursing. 1965;5:11-4.

29. Caceres A, Saravia A, Rizzo S, Zabala L, De Leon E, Nave F. Pharmacologic properties of Moringa oleifera. 2: screening for antispasmodic, antiinflammatory and diuretic activity. J Ethnopharmacology.1992;36(3):233-7.

30. Bhishagratna KK. An English translation of the Sushruta Samhita: based on original Sanskrit text of
Chowkhamba Sanskrit Studies, Chowkhamba Sanskrit Series Office, Varanasi, India. 1991;30(pt 3).

31. Sharma PV. Charaka-Samhita. Agnivesha's Treatise, Refined and Annotated by Charaka and Redacted by Dridhabala, 4 Vols., (Chaukhambha Orientalia, Varanasi), 1981. Available at http://www.bdu.ac.in/schools/biotechnology/industria 1_biotechnology/sekardb/pdf/references/2.pdf.

32. Babu R, Chaudhuri M. Home water treatment by direct filtration with natural coagulant. J Water Health. 2005;3(1):27-30.

33. Ruckmani K, Kavimani S, Anandan R, Jaykar B. Effect of Moringa oleifera lam on paracetamolinduced hepatotoxicity. Indian J Pharmaceutical Sci. 1998;60(1):33-5.

34. Chaudhary RD, Chopra RD. Herbal drug industry: a practical approach to industrial pharmacognosy, Eastern Publishers, New Delhi, India, 1996. Available at http://www.oalib.com/references/13100430.

35. Ghasi S, Nwobodo E, Ofili JO. Hypocholesterolemic effects of crude extract of leaf of Moringa oleifera Lam in high-fat diet fed wistar rats. J Ethnopharmacology 2000; 69(1): 21-25

36. Srinivasan K, Viswanad B, Asrat L, Kaul CL, Ramarao P. Combination of high-fat diet-fed and low-dose streptozotocin-treated rat: a model for type 2 diabetes and pharmacological screening. Pharmacological Res. 2005;52(4):313-20.

37. Novelli EL, Diniz YS, Galhardi CM, Ebaid GM, Rodrigues HG. Anthropometrical parameters and markers of obesity in rats. Lab Anim. 2007;41:111-9.

38. Yun JW. Possible anti-obesity therapeutics from nature-a review. Phytochemistry. 2010;71:1625-41.

39. Rodrigues A, Pereira PC, Vicente AF, Brito JA, Bernardo MA, Mesquita MF. Food intake, body mass index and body fat mass in elderly. Asian J Clin Nutr. 2012;4:107-15.

40. Dongmeza E, Siddhuraju P, Francis G, Becker K. Effects of dehydrated methanol extracts of moringa (Moringa oleifera Lam.) leaves and three of its fractions on growth performance and feed nutrient assimilation in Nile tilapia (Oreochromis niloticus (L.). Aquaculture. 2006;261:407-22.

41. Hassarajani S, Souza TD, Mengi SA. Efficacy study of the bioactive fraction (F-3) of Acorus calamus in hyperlipidemia. Indian J Pharmacol. 2007;39:196200.

42. Jain PG, Patil SD, Haswani NG, Girase MV, Surana SJ, Hypolipidemic activity of Moringa oleifera Lam. Moringaceae, on high fat diet induced hyperlipidemia in albino rats. Brazilian $\mathbf{J}$ Pharmacognosy. 2010;20(6):969-73.

43. Anwar F, Latif S, Ashraf M, Gilani AH, Review Moringa oleifera: a food plant with multiple medicinal use. Phytotherapy Res. 2007;21(1):17-25.

44. Saluja MP, Kapil RS, Popli SP. Studies in medicinal plants: part VI. Chemical constituents of Moringa oleifera Lamk. (hybrid variety) and isolation of 4- 
hydroxymellein. Indian J Chemistry. 1978;16(11):1044-5.

45. Kane JP, Malloy MJ. Treatment of hypercholesterolemia. Medical Clinics of North America. 1982;66:537-50.
46. O’Byme DJ, Devaraj S, Grundy SM, Jialal I. Comparison of antioxidant effects of Concord grape juice flavonoids and $\alpha$ - tocopherol on markers of oxidative stress in healthy adults. Am J Clin Nutr. 2002;76:1367-74.

Cite this article as: Nahar S, Faisal FM, Iqbal J, Rahman MM, Yusuf MA. Antiobesity activity of Moringa oleifera leaves against high fat dietinduced obesity in rats. Int J Basic Clin Pharmacol 2016;5:1263-8. 